\title{
New sightings of false killer whales Pseudorca crassidens (Owen, 1846) in Chile
}

\author{
Nuevos avistamientos de orca falsa Pseudorca crassidens (Owen, 1846) en Chile
}

This work is dedicated in loving memory of Rolando Bernal D.

\author{
Marcelo A. Flores M. ${ }^{1}$, Rodrigo Moraga ${ }^{2}$, María José Pérez ${ }^{3}$, \\ Erika Hanshing ${ }^{4}$ and Carlos Olavarría ${ }^{5}$ \\ ${ }^{I}$ Facultad de Ciencias del Mar, Universidad de Valparaíso, Casilla 5080-Reñaca, Viña del Mar, Chile \\ ${ }^{2}$ Fray Montalva 580, Santiago, Chile \\ ${ }^{3} 1$ Poniente 960 Dpto. 1102, Viña del Mar \\ ${ }^{4}$ Facultad de Ciencias del Mar, Universidad Católica del Norte, Coquimbo, Chile \\ ${ }^{5}$ School of Biological Sciences, University of Auckland Private Bag 92019, Auckland, New Zealand \\ marcelo.flores@uv.cl
}

\begin{abstract}
Resumen.- Con anterioridad, la orca falsa Pseudorca crassidens ha sido escasamente reportada en aguas chilenas. En esta nota damos a conocer tres nuevos registros. El primero corresponde a un grupo observado junto con tursiones (Tursiops truncatus) y calderones de aleta corta (Globicephala macrorhynchus) en bahía Cumberland, isla Robinson Crusoe frente a Chile central. El segundo registro corresponde a un individuo observado por trece meses entre Iquique y San
\end{abstract}

Antonio en el norte y centro de Chile. El tercer registro corresponde a un grupo avistado cerca de la península de Taitao. Se revisa la distribución de esta especie en aguas chilenas.

Palabras clave: Orca falsa, mamíferos marinos, distribución, Pacífico Sur Oriental
The false killer whale Pseudorca crassidens (Owen, 1846) is distributed worldwide. It has been recorded in all tropical, subtropical and warm temperate seas (Stacey et al. 1994). It mainly inhabits deep pelagic waters (Leatherwood \& Reeves 1983) and its distribution generally does not extend beyond $50^{\circ}$ latitude in both hemispheres (Jefferson et al. 1993).

In Chile its presence has been reported rarely (Aguayo et al. 1998a). Its range extends from Iquique (20¹2'S) (Cárdenas \& Yañez 1988'; Findlay et al. 1998) to Magellan Strait (52²7'S) (Oporto et al. 1994; Alonso et al. 1999). It has also been reported in the waters around offshore islands such as Salas y Gómez $\left(26^{\circ} 27^{\prime} \mathrm{S} ; 1^{\circ} 5^{\circ} 28^{\prime} \mathrm{W}\right)$ (Cárdenas \& Yañez op. cit.) and Easter Island $\left(27^{\circ} 09^{\prime} \mathrm{S} ; 1^{109^{\circ}} 23^{\prime} \mathrm{W}\right)$ (Aguayo et al. 1998b) (Fig. 1, Table 1).

\footnotetext{
Cárdenas JC \& J Yáñez. 1988. Importancia del desarrollo de un programa de investigaciones cetológicas en las islas oceánicas chilenas. Primer taller sobre conservación y manejo de mamíferos marinos chilenos. Valdivia, 19-20 de agosto de 1988.13 pp. No publicado.
}

In this note we report three new records of false killer whales, and review its distribution, habits and ocurrence in Chilean waters.

The first new record corresponds to a sighting occurred on March 17 1998, in Cumberland Bay, Robinson Crusoe Island, Juan Fernández Archipelago (333' $\mathrm{S}$; 78 $40^{\circ} \mathrm{W}$ ). A pod of around thirty individuals close to bottlenose dolphins (Tursiops truncatus) and short-finned pilot whales (Globicephala macrorhynchus) were observed entering the bay around 09:00. The interespecific group displayed no noteworthy behaviour, swimming in different directions and diving asynchronously. However, we noticed that false killer whales were mixed with the short-finned pilot whales but not with the bottlenose dolphins. After 30-40 minutes, two boats approached the pod, and no change of behaviour was observed. Two divers entered the water to obtain photographs, without success. The group stayed in the bay for fifty minutes before swimming out to open sea. Local fishermen interviewed after this encounter, reported that they usually see this kind of "blackfish" inside the bay during March. 
The second sighting corresponds to a solitary individual, that was observed between December 25 1999 and January 5 2001, in a large coastal area between Iquique $\left(20^{\circ} 13^{\prime} \mathrm{S} ; 70^{\circ} 10^{\prime} \mathrm{W}\right)$ and San Antonio $\left(33^{\circ} 34^{\prime} \mathrm{S} ; 71^{\circ} 36^{\prime} \mathrm{W}\right)$. The individual was photoidentified using marks on its dorsal fin (Fig. 2). For most of the sightings the whale was undertaking regular short dives and swimming parallel to the coastline between two and ten meters from shore.

The third sighting corresponds to a pod of 15 individuals observed near Taitao Peninsula during the
IWC-SOWER cruise in 1999-2000 (Hucke-Gaete, pers. comm).

P. crassidens has been described as an oceanic species that sometimes approaches islands or landmasses close to deep waters (Leatherwood \& Reeves 1983). This is consistent with the record from Robinson Crusoe, where depths of 500 meters are recorded three miles from the coast (Nautical Chart 5410 SHOA). Similar geography occurs around the other Chilean oceanic islands (Easter Island and Salas y Gómez) where the false killer whale has been reported previously.

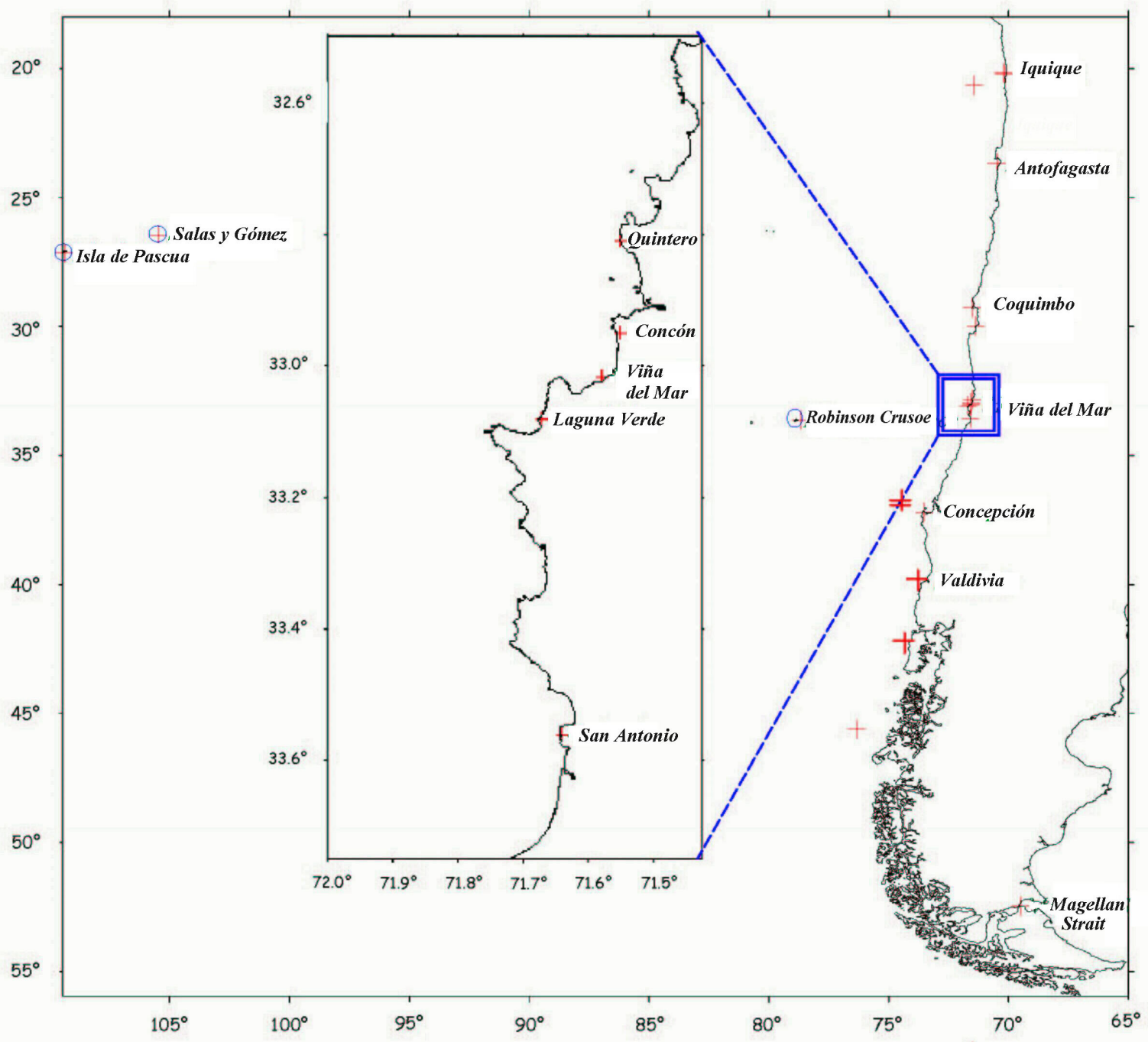

Figure 1

False killer whale sightings in Chile (crosses). The amplified map shows in detail the sightings of the solitary animal in central Chile

Avistamientos de orca falsa en Chile (cruces). El mapa ampliado muestra en detalle los avistamientos del ejemplar solitario en Chile central 
Table 1

\section{Records of false killer whale in Chile}

Registros de orca falsa en Chile

\begin{tabular}{|c|c|c|c|c|}
\hline Date & Location & $\mathbf{N}$ & Observations & Source \\
\hline 1946 & Concepción $37^{\circ} 12^{\prime} \mathrm{S} ; 7^{\circ} 30^{\prime} \mathrm{W}$ & 1 & $\begin{array}{l}\text { One individual stranded in Concepción Bay at } \\
\text { Rocuant Island }\end{array}$ & $\begin{array}{c}\text { Oliver-Schneider } \\
(1946)\end{array}$ \\
\hline oct-81 & $\begin{array}{l}\text { Salas y Gómez island } \\
26^{\circ} 27^{\prime} \mathrm{S} ; 105^{\circ} 28^{\prime} \mathrm{W}\end{array}$ & 10 & & $\begin{array}{c}\text { Cárdenas \& Yánez } \\
\text { (1988) }\end{array}$ \\
\hline 17-jul-83 & $\begin{array}{c}\text { Los Choros, Coquimbo } \\
29^{\circ} 16^{\prime} \mathrm{S} ; 71^{\circ} 32^{\prime} \mathrm{W}\end{array}$ & 103 & Stranded in a $6.0 \mathrm{~km}$ long beach & Fuentes (1987) \\
\hline 12-mar-85 & Playa Huaiquique; Iquique & 1 & & $\begin{array}{c}\text { Cárdenas \& Yánez } \\
\text { (1988) }\end{array}$ \\
\hline 1989 & Eastern Island & $6-10$ & Recorded by H Garcia & Aguayo et al.(1998b) \\
\hline 07-mar-89 & $\begin{array}{l}\text { Eastern side of Magellan Strait } \\
52^{\circ} 27^{\prime} \mathrm{S} ; 69^{\circ} 31^{\prime} \mathrm{W}\end{array}$ & 181 & $\begin{array}{c}\text { Stranded in an extensive area starting from Punta } \\
\left.\text { Delgada (52 } 27^{\prime} \mathrm{S} ; 69^{\circ} 31^{\prime} \mathrm{W}\right) \text { to Bahía Shoal } \\
\left(52^{\circ} 55^{\prime} \mathrm{S} ; 70^{\circ} 54^{\prime} \mathrm{W}\right)\end{array}$ & Alonso et al. (1999) \\
\hline 29-mar-94 & $\begin{array}{c}27^{\circ} 09^{\prime} \mathrm{S} ; 109^{\circ} 23^{\prime} \mathrm{W} \\
\text { Cape Apina, Easter Island }\end{array}$ & 1 & Stranded & Aguayo et al. (1998b) \\
\hline 17-dec-97 & $20^{\circ} 39.67^{\prime} \mathrm{S} ; 71^{\circ} 25.45^{\prime} \mathrm{W}$ & 100 & $\begin{array}{c}\text { A school was observed at 12:25 h. Depth read of the } \\
\text { chart was } 6000-6500 \mathrm{~m}\end{array}$ & $\begin{array}{c}\text { Greg Donovan } \\
\text { (pers. Comm.), } \\
\text { Findlay et al. }(1998)\end{array}$ \\
\hline 17-mar-98 & $\begin{array}{l}\text { Robinson Crusoe } \\
33^{\circ} 37^{\prime} \mathrm{S} ; 78^{\circ} 40^{\prime} \mathrm{W}\end{array}$ & 30 & $\begin{array}{c}\text { Pod mixed with Tursiops truncatus and } \\
\text { Globicephala macrorhynchus }\end{array}$ & This note \\
\hline
\end{tabular}

\begin{tabular}{|c|c|c|c|c|c|}
\hline $\begin{array}{c}\text { 25-dec-99 } \\
\text { to } 05 \text {-jan- } \\
01\end{array}$ & $\begin{array}{c}\text { San Antonio }\left(33^{\circ} 34^{\prime} \mathrm{S} ; 71^{\circ} 36^{\prime} \mathrm{W}\right) \\
\text { to Iquique }\left(20^{\circ} 13^{\prime} \mathrm{S} ; 70^{\circ} 10^{\prime} \mathrm{W}\right)\end{array}$ & 1 & $\begin{array}{l}25 \text {-dec-99 } \\
28 \text {-dec-99 } \\
22 \text {-april-00 } \\
26 \text {-april-00 } \\
13 \text {-may-00 } \\
23 \text {-may-00 } \\
08 \text {-jun-00 } \\
17 \text {-aug-00 } \\
18 \text {-aug-00 } \\
04 \text {-sep-00 } \\
03 \text {-dec-00 } \\
04 \text {-jan-01 } \\
05 \text {-jan-01 } \\
\end{array}$ & 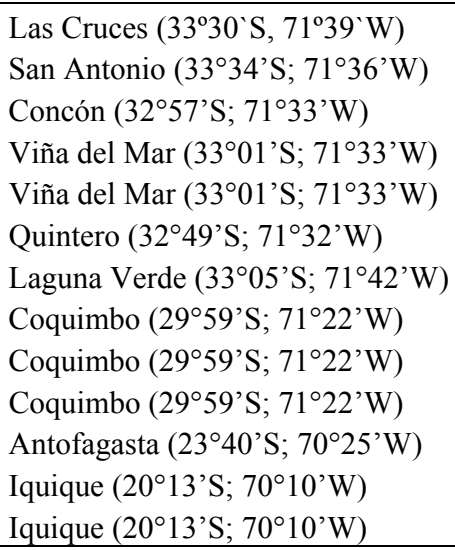 & This note \\
\hline 9-jan-00 & $45^{\circ} 35.86^{\prime} \mathrm{S} ; 76^{\circ} 20.38^{\prime} \mathrm{W}$ & 15 & \multicolumn{2}{|c|}{$\begin{array}{l}\text { (IWC-SOWER) Antarctic cruise surveyed the } \\
\text { eastern part of IWC Antarctic Area I }\end{array}$} & $\begin{array}{c}\text { Hucke-Gaete } \\
\text { (pers. comm.) } \\
\text { This note } \\
\end{array}$ \\
\hline
\end{tabular}




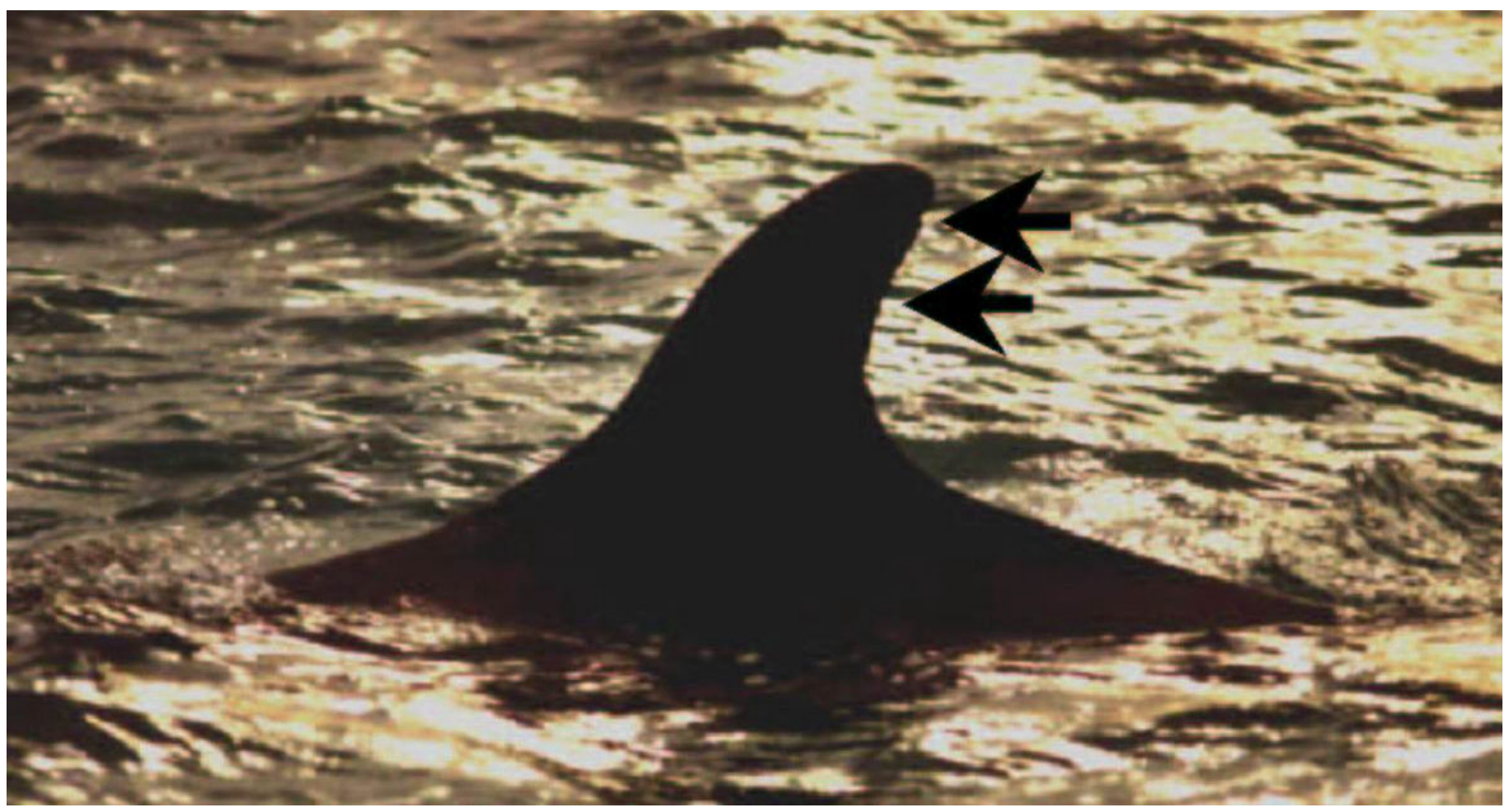

Figure 2

Pseudorca crassidens. Dorsal fin of the solitary individual sighted between San Antonio and Iquique. The arrows show the distinctive notches used for photoidentification

Pseudorca crassidens. Aleta dorsal del individuo solitario avistado entre San Antonio e Iquique.

Las flechas muestran las muescas distintivas utilizadas para fotoidentificación

Although false killer whales have been described as a pelagic gregrarious species (Leatherwood \& Reeves op. cit.), and this is supported with most of the sightings recorded in Chilean waters, the individual regularly observed near the coast in central and north of Chile suggests that this kind of behaviour does not necessary indicate a disablility of the individual. This is also supported by the record of another solitary animal from British Columbia, Canada (Stacey \& Baird 1991).

The distribution of $P$. crassidens off Chile seems to be continous along the northern and central part of the Pacific coast. The stranding recorded in the Magellan Strait may have been from Atlantic Ocean population, based on swimming behaviour (Alonso et al.1999) and oceanographic conditions in the area.

\section{Acknowledgements}

We thank X Fuentes, JL Brito, P López, C Vera and L Prado for field support. To A Aguayo, J Acevedo, W Sielfeld and R Hucke-Gaete for information about the records. Thanks also to $\mathrm{P}$ Niada and $\mathrm{C}$ Atal for video and photographic records of the Robinson Crusoe sighting. Thanks to $\mathrm{G}$ Donovan for providing access to IWC sightings data. E Newcombe helped with the english version. Finally to all the members of "eutropia group", without their efforts the tracking of the solitary animal would not have been possible.

\section{Literature cited}

Aguayo A, D Torres \& J Acevedo. 1998a. Los mamíferos marinos de Chile: Cetacea. Serie Científica Instituto Antártico Chileno 48: 19-159.

Aguayo A, R Bernal, C Olavarría, V Vallejos \& R HuckeGaete. 1998b. Observaciones de cetáceos realizadas entre Valparaíso e Isla de Pascua, Chile, durante los inviernos de 1993, 1994 y 1995. Revista de Biología Marina y Oceanografía 33 (1): 101-123.

Alonso M, S Pedraza, A Schiavini, RNP Goodall \& E Crespo. 1999. Stomach contents of false killer whales (Pseudorca crassidens) stranded on the coasts of the Strait of Magellan, Tierra del Fuego. Marine Mammal Science 15(3): 712-724.

Findlay K, R Pittman, T Tsurui, K Sakai, P Ensor, H Iwakami, D Ljungblad, H Shimada, D Thiele, K Van Waerebeek, R Hucke-Gaete \& GP Sanino. 1998. 1997/1998 IWC-Southern Ocean Whale and Ecosystem Research (IWC-SOWER) Blue Whale Cruise, Chile. Documento técnico. IWC. Muskat, Omán. 39 pp. (no publicado). 
Fuentes HR. 1987. Observaciones sobre Pseudorca crassidens (Owen 1846) (Odontoceti: Delphinidae) varadas en Los Choros, Coquimbo, IV Región, Chile. Anales del Museo de Historia Natural de Valparaíso 18: 169-175.

Jefferson T, S Leatherwood \& M Webber. 1993. FAO Species Identification Guide. Marine Mammals of the World. Rome, FAO. 320 pp.

Leatherwood $\mathbf{S} \& \mathbf{R}$ Reeves. 1983. The Sierra Club Handbook of Whales and Dolphins. Sierra Club Books. San Francisco. 302 pp.

Oliver-Schneider C. 1946. Catálogo de mamíferos de Concepción. Boletín de la Sociedad de Biología de Concepción (Chile) 21: 67-83.
Oporto H, A Lescrauwaet, $\mathbf{N}$ Maslow, R Matus, J Canto \& O Turina. 1994. Primeros antecedentes ambientales de un varamiento masivo de falsa orca (Pseudorca crassidens), ocurrido en el estrecho de Magallanes, Chile. In: Anales de la IV Reunión de Trabajo de Especialistas en Mamíferos Acuáticos de América del Sur, pp. 277-285.

Servicio Hidrográfico y Oceanográfico de la Armada de Chile. 1999. Carta Náutica $N^{\circ} 5410$.

Stacey PJ \& RW Baird. 1991. Status of the false killer whale, Pseudorca crassidens, in Canada. Canadian FieldNaturalist 105 (2): 189-197.

Stacey PJ, S Leatherwood \& RW Baird. 1994. Pseudorca crassidens. Mammalian Species 456: 1-6. 